\title{
The Effect of Using the Interactive E Developing English Writing Skills - Learning on of Second Preparatory Stage \\ Graders
}

By

Ahmed Nasrat Mohamed Roshdy

\section{$\underline{\text { Abstract }}$}

The current study aimed at developing English writing skills of second preparatory stage graders through using the interactive elearning. The main question is: "What is The Effect of Using the Interactive E -Learning on Developing English Writing Skills of Second Preparatory stage graders?" The pre-post control group design was used in the current study. The study sample consisted of (60) second preparatory graders from Nazlet Al-Nakhl prep school, in Abu Korkas Educational Administration, Minia Governorate. Then, they were divided into the control $(n=30)$ and the experimental group $(n=$ 30). The students of the experimental group received English writing skills instruction through the proposed e-learning interactive activities of the website which was developed by the researcher for the purpose of the current study, while the students of the control group received regular instruction. The tools of the study include: a pre/post writing online test, a questionnaire of learners' perceptions about the e-learning activities. The results showed that there was statistically significant difference at the level of 0,01 between the mean scores of the control and the experimental groups on the post test in favor of the experimental group in overall writing skills as well as in each writing skill. Also, the qualitative results revealed that the participants of the experimental 
group accepted the e-learning interactive material and activities, which means that the e-learning material of the current study is effective in developing second prep graders English writing skills.

Key words: e-learning, interactive, writing skills 
العنوان: أثر استخدام التعلم الاكتروني التفاعلي على تنمية مهارات الكتابة في اللغة الإنجليزية لاى طلاب الصف الثانى الإعدادي السؤال الرئيسي للبحث: ما أثر استخدام التعلم الاككتروني التفاعلي على تتمية مهارات الكتابة في اللغة الإنجليزية لدى طلاب الصف الثانى الإعدادي؟ منهج البحث:استخدم المنهج شبة التجريبى فى الدراسة الحالية وفقا لطبيعة البحث لقياس أثر التعلم الالكتروني على تتمية مهارات كتابة اللغة الانجليزية لاى طلاب الصف الثانى

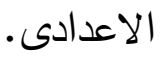
العينة:تتألف عينة الدراسة من 60 طالبة و طالبة من الصف الثانى الإعدادى بمدرسة نزلة النخل الإعدادية التابعة لإدارة أبوقرقاص التعليمية بمحافظة المنيا. الأدوات: الاختبار التحصيلى لتتييم بعض مهارات كتابة اللغة الانجليزية، أنشطة تعلم الكتروني لتدريس بعض مهارات كتابة اللغة الإنجليزية لطلاب الصف الثاني الإعدادي وفقاً للمنهج المقرر لسلسلة " Hello " . إستبيان خاص بأراء الطلاب حول أنشطة التعلم الإكترونى. النتائج: هناك فرق ذو دلالة إحصائية( لصالح المجموعة التجريبية) بين متوسطى درجات المجموعة التجريبية ودرجات المجموعة الضابطة فى التطبيق البعدى لإختبار قياس مهارات كتابة اللغة الانجليزية. و أيضا كل مهارة على حدا مما يثبت فاعلية التعلم الإكترونى فى تطوير مهارات كتابة اللغة الإنجليزية. التوصيات:إجراء المزيد من الأبحاث لمعرفة مدى فاعلية التعليم الإلكترونى فى تطوير باقى مهارات اللغة الإنجليزية مثل القراءة أو التحدث، إجراء المزيد من الأبحاث للتأكد من فاعلية 
التعلم الإكترونى فى تطوير مهارات باقى اللغات الأجنبية و الإستفادة من خبرة التعلم الإلكترونى فى مدارس جمهورية مصر العربية. 


\section{Introduction:}

Learning foreign language skills, especially English language skills as the first international language is very important and can be vital, for the purpose of communication with other cultures and to deal with modern technology in the various life fields.

The ultimate purpose of language learning is basically to get learners to use it for communicating with other individuals who speak the language. Thus the main goal of English language teaching is to develop EFL learners' ability to communicate with people in English in real world situations and to express themselves in this language (Brown, 1987; Ommagio, 1986: 12). With the advent of internet technology, and its applications to teaching and learning, many students practice their writing skills synchronously as in chatting, instant messaging, and live discussion boards (smith, 2006: 7)

It is claimed that the " $\mathrm{e}$ " in eLearning stands for electronic, but we should claim that it stands for "evolving, enhanced, extended, everywhere, every time, and everybody" (Li \& Masters, 2009:45).

Writing is a powerful instrument of thinking because it provides students with a way of gaining control over their thoughts. And there is a relation between reading and writing, the more students read, the more fluently they will write (Hogue, 2008).

Seuss (1990) stated that the path of e- learning is taking on some likenesses in that journey of exploration as well. Online training is here as a viable mode of instruction (Rosenberg, 2001). However, Rosenberg (2001) reminds us that training packages should not be 
replications of stand-up training. Structure can vary, but the learners' needs and the learning situation should always be foremost in the minds of the training professional.

Shirley Alexander, (2001: 240) pointed out that; the focus of much e-learning activity is upon the development of courses and their resources. Successful e-learning takes place within a complex system involving the student experience of learning, teachers' strategies, teachers' planning and thinking, and the teaching/learning context. Staff development for e-learning focuses around the level of technological delivery strategies when other issues such as the teachers' conception of learning has a major influence on the planning of courses, development of teaching strategies and what students learn. Web-based media has changed the way individuals communicate and form relationships, but the use of such media for structured learning is new. Today almost every faculty member in a higher education institution has the ability to build a course website that enables interaction between students and faculty (Dornish\& Land, 2002: 77).

Online learning has a number of potential benefits, not least of which is the ability to overcome the temporal and spatial restrictions of traditional educational settings (Bates, 2005: 19).

Rema (2009:27) indicated that using an e-learning program for developing the English language writing skills of the first graders at the faculty of Language and Translation, King Saud university, K.S.A, compared with the traditional teaching, which depends on the printed book, led to a statistical significant improvement of the 
weak female students English language writing skills ,and recommended to use the e-learning at all the English study stages also to train English teachers on using the e-learning in their teaching.

Chui's study (2005) pointed out that communication, when pedagogically employed, can lead to better classroom interaction and creative learning.

Online courses create unique environments that require thoughtful care for instructors to help students become engaged in their learning and to design virtual classrooms that enhance a sense of community (Meyers, 2008:102).

According to Berge (2002) and Northrup (2002), when instructors carefully plan ways for students to interact, students can focus on achieving course learning goals. Students who learn the most from online courses have online instructors who provide a structured and comfortable classroom environment that involves the participation of everyone in the learning activities (Young, 2006: 7).

When the researcher examined the English scores of the second prep students as it will be shown in the problem statement, and when he interviewed ten English teachers from four different schools in Minia Governorate, it was found out that there was a problem in some writing skills of those students who are taught by regular ways such as; using suitable tenses, using suitable vocabulary, expressing ideas, punctuation, etc.

\section{Context of the Problem:}


Through the observation of the researcher in some classrooms, as he worked as an English teacher, it was found out that the second preparatory school graders had some difficulties in writing English. To investigate the problem, the researcher used two tools for this purpose. First, the researcher interviewed ten English teachers at the prep stage from four different schools; "Mansafes prep school, Nazlat El Nakhl prep school, Qasem Amin prep school and Menshaat Alfekryah prep school" in Abu Korkas directorate. Most of them agreed that their students at the preparatory stage cannot write English well and their scores in the writing test are very low.

The second procedure that the researcher used to investigate the problem was to examine the students' scores in a test, as he analyzed The English scores of (318) second prep students from Mansafes Prep School at the first semester, which revealed the following.:

Table (1): The English scores of (318) second prep students from Mansafes Prep School at the first semester

\begin{tabular}{|c|c|c|c|c|c|}
\hline $\begin{array}{c}\text { Total } \\
\text { number }\end{array}$ & $\begin{array}{c}\text { Excellent } \\
\text { students }\end{array}$ & $\begin{array}{c}\text { Very } \\
\text { good } \\
\text { students }\end{array}$ & $\begin{array}{c}\text { Good } \\
\text { students }\end{array}$ & $\begin{array}{c}\text { Passed } \\
\text { students }\end{array}$ & $\begin{array}{c}\text { Failed } \\
\text { students }\end{array}$ \\
\hline 318 & 20 & 7 & 23 & 106 & 162 \\
\hline
\end{tabular}


Table (2): The writing questions scores of the same test:

\begin{tabular}{|c|c|c|c|c|c|}
\hline $\begin{array}{c}\text { Total } \\
\text { number }\end{array}$ & $\begin{array}{c}\text { Excellent } \\
\text { students }\end{array}$ & $\begin{array}{c}\text { Very } \\
\text { good } \\
\text { students }\end{array}$ & $\begin{array}{c}\text { Good } \\
\text { students }\end{array}$ & $\begin{array}{c}\text { Passed } \\
\text { students }\end{array}$ & $\begin{array}{c}\text { Failed } \\
\text { students }\end{array}$ \\
\hline 318 & 17 & 18 & 15 & 51 & 217 \\
\hline
\end{tabular}

Students were asked in the writing test to look at a picture and write four sentences, and then there was a question for punctuation. The common errors of students were at the sentence formation, using suitable vocabulary, forming sentences, using conjunctions, punctuation, and spelling.

\section{Statement of the problem:}

That the second preparatory school graders suffered from some difficulties in writing English, so the current study attempted to investigate:"The Effect of Using the Interactive E -Learning on Developing English Writing Skills of Second Preparatory stage graders"

\section{Question of the study:}

The present study attempted to answer the following question: "What is The Effect of Using the Interactive $\mathbf{E}$-Learning on Developing English Writing Skills of Second Preparatory stage graders?"

The following Sub-questions are derived from the main question:

1- What is the effect of using the interactive $E$-Learning on developing the skill of writing grammatically correct sentences and matching them using relative pronouns by second preparatory stage graders? 
2- What is the effect of using the interactive $E$-Learning on developing the skill of writing an English e-mail by second preparatory stage graders?

3- What is the effect of using the interactive $E$-Learning on developing the skill of writing a short paragraph of five sentences by second preparatory stage graders?

4- What is the effect of using the interactive $E$-Learning on developing the skill of punctuation by second preparatory stage graders?

5- What is the effect of using the interactive $E$-Learning on developing the skill of describing pictures with the suitable sentences by second preparatory stage graders?

\section{Study hypotheses:}

- There is a statistically significant difference (favoring the experimental group) between means scores obtained by the experimental and control group on the post test for the skill of writing grammatically correct sentences and matching them using relative pronouns.

- There is a statistically significant difference (favoring the experimental group) between means scores obtained by the experimental and control group on the post test for the skill of writing an English e-mail.

- There is a statistical significant difference (favoring the experimental group) between means scores obtained by the experimental and control group on the post test for the skill of writing a short paragraph of five sentences 
- There is a statistical significant difference (favoring the experimental group) between means scores obtained by the experimental and control group on the post test for the skill of punctuation

- There is a statistical significant difference (favoring the experimental group) between means scores obtained by the experimental and control group on the post test for the skill of describing pictures with the suitable sentences

- There is a statistical significant difference (favoring the post test) between means scores obtained by the experimental group on the pre and post writing test.

\section{Aims of the study:}

The current study attempted to enhance the performance of EFL learners in the skill of:

1- writing grammatically correct sentences and matching them using relative pronouns by second preparatory stage graders.

2- writing an English e-mail by second preparatory stage graders.

3- writing a short paragraph of five sentences by second preparatory stage graders.

4- punctuation by second preparatory stage graders.

5-describing pictures with the suitable sentences by second preparatory stage graders.

\section{Experimental design:}

A pre - post experimental control group design was applied in the present research according to the research nature to 
evaluate the effect of the interactive e- learning on developing

English writing skills of second preparatory stage graders.

\section{The study sample:}

The study was conducted in Nazlet Al-Nakhl prep school, in Abu Korkas educational directorate, Minia governorate in the second term of 2013-2014. The study sample consisted of 60 students which were divided equally into the experimental group $(n=30)$ and the control group $(n=30)$. The average age of those students was ranged from 12-13 years.

\section{Study variables:}

The present study included the following variables:

1- The independent variable: using the e- learning

2- The dependent variables: Developing some of the English writing skills of the second prep school students.

3- The control variable: Achievement level.

- Tools of the study:

1- An achievement test of English writing skills for the second prep. Graders to evaluate some English writing skills.

2- Some e-learning activities to develop some of the writing skills related to the second prep English curriculum.

3- Interview form, which was used in the pilot study.

4- An interview form for learner evaluation of the e-learning activities. 


\section{Study procedures:}

1- Reviewing the literature related to the relationship between E-learning and developing the English writing skills.

2- Stating some English writing skills for second preparatory year according to the teachers guide.

3- Defining English writing skills, which need development.

4- Selecting the study sample from the second prep graders then dividing them to a control group and an experimental group.

5- Equating the control and the experimental group at the control variables.

6- Constructing the study tools

7- Administering the pre-test to the second prep graders of both the experimental group and the control group

8- Using the appropriate statistical methods to analyze the obtained data.

9- Applying the E-learning activities, which are related to the English writing skills

10-Administrating the post-test to evaluate the degree of improvement in the experimental group and the control group.

11- Using the appropriate statistical methods to analyze the obtained data.

12-Discussing the results.

13- Providing the recommendation and suggestions for future research. 


\section{Material:}

The researcher used the interactive e-learning through an interactive website whose material was developed by the researcher and was designed by a web developer. The website is www.prepwritngskills.com that includes six writing lessons which are selected after reviewing the student book and the teacher guide of hello series for the second prep grade. Each lesson is ended with some interactive activities for learners to be answered and e-mailed to my e-mail address then learners were given feedback on their writing.

* The e-learning site included six lessons with activities:

- Writing an e-mail.

- The relative pronouns.

- The simple sentence formation.

- Writing a short paragraph of five sentences.

- Describing pictures

- Punctuation rules

Each lesson contained formative and summative evaluation items Results related to the study hypotheses: 


\section{1- Verifying the first hypothesis:}

Table (4): $t$-value of the post comparison between the experimental group and the control group in the skill of writing grammatically correct sentences and matching them with relative pronouns

\begin{tabular}{|c|c|c|c|c|c|}
\hline $\begin{array}{c}\text { The administration of } \\
\text { the post test }\end{array}$ & $\mathbf{N}$ & Mean & $\begin{array}{c}\text { Standard } \\
\text { deviation }\end{array}$ & $\begin{array}{c}\text { t- } \\
\text { value }\end{array}$ & Sig. \\
\hline The control group. & 30 & 3.23 & 1.25 & \multirow{2}{*}{7.21} & 0.000 \\
\hline The experimental group. & 30 & 5.73 & 1.43 & & \\
\hline
\end{tabular}

From the above table, it is pointed out that the calculated $t$ - value reached (7.21) was higher than the table value of $(t)$ at the level of (0.01). This means that there are statistically significant differences between the two groups in favor of the post administration of the experimental group, so the experiment had an effect on acquisition of the research subjects for the skill of writing correct grammatically sentences and matching them with relative pronouns.

\section{2- Verifying the second hypothesis:}

Table (5): $t$-value of the post comparison between the experimental group and the control group in the skill of writing an English e-mail

\begin{tabular}{|c|c|c|c|c|c|}
\hline $\begin{array}{c}\text { The administration } \\
\text { of the post test }\end{array}$ & $\mathbf{N}$ & Mean & $\begin{array}{c}\text { Standard } \\
\text { deviation }\end{array}$ & t-value & Sig. \\
\hline The control group. & 30 & 4.87 & 2.08 & \multirow{2}{*}{7.32} & 0.000 \\
\hline $\begin{array}{c}\text { The experimental } \\
\text { group. }\end{array}$ & 30 & 8.22 & 1.40 & & \\
\hline
\end{tabular}

From the above table, it is pointed out that the calculated $T$ - value reached $(7,32)$ which was higher than the table value of $(T)$ at the 
level of (0.01). This means that there were statistically differences between the two groups in favor of the post administration of the experimental group, so the experiment had an effect on acquisition of the research subjects for the skill of writing an English e-mail.

3- Verifying the third hypothesis:

Table (6): $t$-value of the post comparison between the experimental group and the control group in the skill of writing a short paragraph of five sentences:

\begin{tabular}{|c|c|c|c|c|c|}
\hline $\begin{array}{c}\text { The administration of } \\
\text { the post test }\end{array}$ & $\mathbf{N}$ & Mean & $\begin{array}{c}\text { Standard } \\
\text { deviation }\end{array}$ & t-value & Sig. \\
\hline The control group. & 30 & 3.50 & 1.57 & 15.43 & 0.000 \\
\hline The experimental group. & 30 & 9.78 & 1.58 & & \\
\hline
\end{tabular}

From the above table, it is pointed out that the calculated $t$ - value reached $(15,43)$ was higher than the table value of $(t)$ at the level of (0.01). This means that there were statistically significant differences between the two groups in favor of the post administration of the experimental group, so the experiment had an effect on acquisition of the research subjects for the skill of writing a short paragraph of five sentences.

\section{4-Verifying the fourth hypothesis:}

Table (7): $t$-value of the post comparison between the experimental group and the control group in the skill of punctuation

\begin{tabular}{|c|c|c|c|c|c|}
\hline $\begin{array}{c}\text { The administration of } \\
\text { the post test }\end{array}$ & $\mathbf{N}$ & Mean & $\begin{array}{c}\text { Standard } \\
\text { deviation }\end{array}$ & t-value & Sig. \\
\hline The control group. & 30 & 1.80 & 0.85 & \multirow{2}{*}{9.11} & 0.000 \\
\hline The experimental group. & 30 & 3.87 & 0.91 & & \\
\hline
\end{tabular}

From the above table, it is pointed out that the calculated $T$ - value reached $(9,11)$ was higher than the table value of $(T)$ at the level of (0.01). This means that there were statistically differences between 
the two groups in favor of the post administration of the experimental group, so the experiment had an effect on acquisition of the research subjects for the skill of punctuation.

The following figure points out the differences between the means scores in the post application for the two groups

5-Verifying the fifth hypothesis:

\begin{tabular}{|c|c|c|c|c|c|}
\hline $\begin{array}{c}\text { The administration of } \\
\text { the post test }\end{array}$ & $\mathbf{N}$ & Mean & $\begin{array}{c}\text { Standard } \\
\text { deviation }\end{array}$ & t-value & Sig. \\
\hline The control group. & 30 & 2.40 & 0.73 & \multirow{2}{*}{8.55} & 0.000 \\
\hline The experimental group. & 30 & 4.07 & 0.78 & & \\
\hline
\end{tabular}

From the above table, it is pointed out that the calculated $t$ - value reached $(8,55)$ was higher than the table value of $(t)$ at the level of (0.01). This means that there were statistically significant differences between the two groups in favor of the post administration of the experimental group, so the experiment had an effect on acquisition of the research subjects for the skill of describing pictures with the suitable vocabulary.

6-Verifying the sixth hypothesis:

Table (9): $t$-value of the post comparison between the experimental group and the control group in English writing skills

\begin{tabular}{|c|c|c|c|c|c|}
\hline $\begin{array}{c}\text { The administration of } \\
\text { the post test }\end{array}$ & $\mathbf{N}$ & Mean & $\begin{array}{c}\text { Standard } \\
\text { deviation }\end{array}$ & t-value & Sig. \\
\hline The control group. & 30 & 15.80 & 4.17 & \multirow{2}{*}{14.97} & 0.000 \\
\hline The experimental group. & 30 & 31.67 & 4.01 & & \\
\hline
\end{tabular}

From the above table, it is pointed out that the calculated $T$ - value reached $(14,97)$ was higher than the table value of $(T)$ at the level of (0.01). This means that there were statistically differences between the two groups in favor of the post administration of the 
ISSN Print: (2090-0090)

experimental group, so the experiment had an effect on acquisition

of the research subjects for the English writing skills.

Results of the evaluation questionnaire of the opinions of learners

regarding the e-learning website and the course

\begin{tabular}{|c|c|c|c|c|c|c|c|}
\hline n. & item & & yes & partially & no & $\begin{array}{c}\text { Chi- } \\
\text { Square } \\
\text { Test }\end{array}$ & Sig. \\
\hline \multirow[t]{2}{*}{1} & \multirow{2}{*}{$\begin{array}{l}\text { Was the material easy } \\
\text { and clear? }\end{array}$} & $f$ & 23 & 7 & - & \multirow{2}{*}{27.80} & \multirow{2}{*}{0.000} \\
\hline & & $\%$ & 76.67 & 23.33 & - & & \\
\hline \multirow[t]{2}{*}{2} & \multirow{2}{*}{$\begin{array}{l}\text { Was the site interesting } \\
\text { and attractive? }\end{array}$} & $f$ & 25 & 4 & 1 & \multirow{2}{*}{34.20} & \multirow{2}{*}{0.000} \\
\hline & & $\%$ & 83.33 & 13.33 & 3.33 & & \\
\hline \multirow[t]{2}{*}{3} & \multirow{2}{*}{$\begin{array}{l}\text { Did the site help at } \\
\text { improving your writing } \\
\text { performance? }\end{array}$} & $f$ & 19 & 9 & 2 & \multirow{2}{*}{14.60} & \multirow{2}{*}{0.001} \\
\hline & & $\%$ & 63.33 & 30.00 & 6.67 & & \\
\hline \multirow[t]{2}{*}{4} & \multirow{2}{*}{$\begin{array}{l}\text { Did the site help you to } \\
\text { participate and respond } \\
\text { to questions? }\end{array}$} & $f$ & 20 & 8 & 2 & \multirow{2}{*}{16.80} & \multirow{2}{*}{0.000} \\
\hline & & $\%$ & 66.67 & 26.67 & 6.67 & & \\
\hline \multirow[t]{2}{*}{5} & \multirow{2}{*}{$\begin{array}{ll}\text { Were } & \text { activities } \\
\text { sufficient? } & \\
\end{array}$} & $f$ & 19 & 8 & 3 & \multirow{2}{*}{14.60} & \multirow{2}{*}{0.001} \\
\hline & & $\%$ & 63.33 & 26.67 & 10.00 & & \\
\hline \multirow[t]{2}{*}{6} & \multirow{2}{*}{$\begin{array}{l}\text { Was the layout } \\
\text { appropriate for the } \\
\text { content? }\end{array}$} & $f$ & 29 & 1 & - & \multirow{2}{*}{54.20} & \multirow{2}{*}{0.000} \\
\hline & & $\%$ & 96.67 & 3.33 & - & & \\
\hline \multirow[t]{2}{*}{7} & \multirow{2}{*}{$\begin{array}{l}\text { Was the teacher } \\
\text { feedback sufficient? }\end{array}$} & $f$ & 27 & 3 & - & \multirow{2}{*}{43.80} & \multirow{2}{*}{0.000} \\
\hline & & $\%$ & 90.00 & 10.00 & - & & \\
\hline \multirow[t]{2}{*}{8} & \multirow{2}{*}{$\begin{array}{l}\text { Was your } \\
\text { communication with } \\
\text { the teacher through the } \\
\text { site and the e-mail } \\
\text { effective? }\end{array}$} & $f$ & 27 & 3 & - & \multirow{2}{*}{43.80} & \multirow{2}{*}{0.000} \\
\hline & & $\%$ & 90.00 & 10.00 & - & & \\
\hline \multirow[t]{2}{*}{9} & \multirow{2}{*}{$\begin{array}{l}\text { Was the online testing } \\
\text { better than the paper } \\
\text { and pencil testing? }\end{array}$} & $f$ & 16 & 7 & 7 & \multirow{2}{*}{5.40} & 0067 \\
\hline & & $\%$ & 53.33 & 23.33 & 23.33 & & 0.067 \\
\hline 10 & & $f$ & 21 & 6 & 3 & 18.60 & 0.000 \\
\hline
\end{tabular}

Site: https://mathj.journals.ekb.eg Email:jredupsycho@mu.edu.eg 


\begin{tabular}{|l|l|c|c|c|c|c|c|}
\hline n. & & yes & partially & no & $\begin{array}{c}\text { Chi- } \\
\text { Square } \\
\text { Test }\end{array}$ & Sig. \\
\hline $\begin{array}{l}\text { Was the course } \\
\text { duration suitable for } \\
\text { you? }\end{array}$ & $\%$ & $\mathbf{7 0 . 0 0}$ & $\mathbf{2 0 . 0 0}$ & $\mathbf{1 0 . 0 0}$ & & \\
\hline Average & & $\mathbf{2 2 . 6 0}$ & $\mathbf{5 . 6 0}$ & $\mathbf{1 . 8 0}$ & & \\
\hline
\end{tabular}

The abovementioned table shows learner responses to the evaluation questionnaire regarding the course content and the elearning site. According to the figures, it can be said that most learners agreed on the course content and the e-learning website, so it reflects the effectiveness of the e-learning experiment. However some of them saw that online testing was not better enough than paper and pencil testing.

\section{Discussion of Results:}

Results of the research confirmed that there is a development in student level of achievement after the treatment. Means of the scores in the posttest and the obtained t-value in the pre-post test of the experimental group were in favor of the posttest results, and the t-value was significant. That supports the research hypotheses. And also that means the learners of the experimental group developed their writing skills. This development of English writing skills might be attributed to a number of factors, which include applying e-learning activities, peer and group work, varied evaluations, communication between the researcher (the teacher) and the learners through the internet, the interactivity, receiving feedback, and using time effectively during the English class at the multimedia lab or at home as the e-learning activities are available 
on the website twenty four hours, so learners can visit them at any time from any place.

Results of the meta-analysis of Means $(2009 ; 3)$ for research studies from1996 through July 2008 on online learning research studies agree with the present study that "on average, student in online learning conditions performed better than those receiving face-to-face instruction".

The study of Rema (2009:27) agree with the present study as it indicated that using an e-learning program for developing the English language writing skills of the first graders at the faculty of Language and Translation, King Saud university, K.S.A, compared with the traditional teaching, which depends on the printed book ,led to a statistical significant improvement of the weak female students English language writing skills , and recommended to use the e-learning at all the English study stages also to train English teachers on using the e-learning in their teaching.

Also, the study by Neu and Scarcella (1991) found that students had positive attitudes towards reading and writing with computers and less apprehension about writing, and more importantly, students developed better attitudes towards reading and writing with computers; this corresponded with better writing Language and knowing: learning and writing. 


\section{Recommendations:}

- E-learning should receive more attention from the ministry of education, as it should include e-learning activities in school subjects.

- Ministry of education should give more attention for training English teaching on using e-learning at their classes.

- Teachers should apply the present e-learning activities to develop their learners English writing skills.

\section{Suggestions for further studies:}

- Further studies and research are needed in the field of developing other English language skills such as speaking skills by using the e-learning.

- Further studies and research are needed in the field of developing writing skills by e-learning in other languages.

- Further studies and research are needed about online testing and providing online feedback to learners by their teachers. 


\section{References}

- Bates, A. W. (2005). Technology, e-learning and distance (2nd ed.).

New York: Routledge Falmer.

-Berge, Z. L. (2002).Active, interactive and reflective e-learning. The

Quarterly Review of Distance Education 3(2)

- Brown, H.D (1987).Principles of Language learning and teaching-

Englewood Cliffs, N.J Prentice -Hall

- Chiu, C (2005), writing in English: perspectives of an ethnic Chinese

teacher and her students, PHD thesis, the University of New Mexico.

- Dornish, M., \& Land, S. (2002). A conceptual framework for the integration of multiple perspectives with distributed learning environments. Journal of Computing in Higher Education, 14( 1),

-Hogue (2008), First Steps in Academic Writing, second edition, Pwarson Longman Publisher

- Li, H., \& Masters, J. (2009). ELearning and knowledge management in the early years: Where are we and where should we go. Knowledge Management and eLearning: $\underline{\boldsymbol{A n}}$ International Journal, 1(4), 245-250.

- Means, B. , Toyama, Y., Murphy, R., Bakia, M., \& Jones, K. (2009).

Evaluation of evidence-based practices in online learning: A meta-analysis and review of online learning studies. Washington, D.C.

- Meyers, S. (2008). Using transformative pedagogy when teaching online. College Teaching, 56 (4) 
-Neu, J. \&Scarcella, R. (1991). Word processing in the ESL classroom: a survey of student attitudes. In P. Dunkel (Ed.), Computer-assisted language learning and testing, 169-187. Rowley, MA: Newbury House.

- Northrup, P. T. (2002). Online learners' preferences for interaction. The Quarterly Review of Distance Education, 3 (2)

-Ommangio,A.(1986). Teaching language in context- Boston: Heinle and Heinle.

-Rema .S.A (2009), the effectiveness of using the E-learning in the English language learning", PHD thesis, King Saud university, K.S.A

-Seus (1990) "Oh, the places you will go!".New York, Random House inc.

- Shirley Alexander, (2001) E-learning developments and Experiences, Education + Training, 43 (4/5), pp.240 $-248$

-Smith, C. (2006). Synchronous Discussion in Online Courses: A Pedagogical Strategy for Taming the Chat Beast. Retrieved from: www.innovateonline.info/index.php?view=article\&id $=246 \&$ action $=$ article

- Young, S. (2006). Student views of effective online teaching in higher education, American Journal of Distance Education $20(2)$ 